\title{
27. SEDIMENTARY FACIES EVOLUTION OF THE NANKAI FOREARC AND ITS IMPLICATIONS FOR THE GROWTH OF THE SHIMANTO ACCRETIONARY PRISM ${ }^{1}$
}

\author{
Asahiko Taira ${ }^{2}$ and Juichiro Ashi ${ }^{2}$
}

\begin{abstract}
A combination of Deep Sea Drilling Project-Ocean Drilling Program drilling results and site survey data in the Shikoku Basin, Nankai Trough, and Nankai landward slope region provides a unique opportunity to investigate the sedimentary facies evolution in the clastic-dominated accretionary forearc. Here, we consider the facies evolution model based on the drilling results, IZANAGI sidescan images, and seismic reflection profiles.

The sedimentary facies model of the Nankai forearc proposed in this paper is composed of two parts: the ocean floor-trenchlower slope sedimentary facies evolution and the upper slope to forearc basin sedimentary facies evolution. The former begins with basal pelagic and hemipelagic mudstones overlain by a coarsening upward sequence of trench turbidites which are, in turn, covered by slope apron slumps and lower slope hemipelagic mudstone. This assemblage is progressively faulted and folded into a consolidated accretionary prism that is then fractured and faulted in the upper slope region. Massive failure of the seafloor in the upper slope region produces olistostrome deposits that contain lithified blocks derived from older accretionary prism dispersed in a mud matrix. The contact between the older accretionary prism and the upper slope olistostrome is a submarine unconformity that is the first stratigraphic evidence for the exhumation of an older prism to the seafloor. The olistostrome beds are then overlain by forearc basin-plain mudstone and turbidites which are progressively covered by coarsening-upward delta-shelf sequences. An application of the forearc facies model to the Shimanto Belt was attempted in order to ensure feasibility of this model. Several characteristic lithologies observed in the Shimanto Belt can be interpreted with this model. The unconformities found in the Shimanto Belt were evaluated to provide an estimate for the exhumation rate of the prism. Comparison with independent measurement of exhumation rate provides a 0.5 to $1 \mathrm{~km} / \mathrm{m}$.y. vertical growth of the prism.
\end{abstract}

\section{INTRODUCTION}

Sedimentation in trench-to-forearc regions is controlled by a complex interaction between tectonics, volcanism, sea-level change, and other factors such as climate and vegetation (Pickering et al., 1989). Understanding of sedimentary facies and stratigraphic evolution in modern trench-forearc regions will aid greatly the interpretation of ancient accretionary complexes and should help us to gain insight into an important objective of convergent margin geology: the growth and exhumation rate of an accretionary prism.

Ocean Drilling Program (ODP) Leg 131 drilled a complete stratigraphic sequence from the slope apron sedimentary cover down to oceanic basement at the toe region of the Nankai accretionary prism (Taira, Hill, Firth, et al., 1991). The result, together with previous Deep Sea Drilling Project (DSDP) data in this region (Karig, Ingle, et al., 1975; Klein, Kobayashi, et al., 1980; Kagami, Karig, Coulbourn, et al., 1986) provides the best example for clastic sedimentation in modern trench environments.

The results of recent swath mapping surveys including SeaBeam (Le Pichon et al., 1987) and IZANAGI sidescan sonar (Ashi and Taira, in press), together with continuously accumulated seismic profile data (Nasu et al., 1982; Aoki et al., 1983; Kaiko I Research Group, 1986; Taira et al., 1988; Moore et al., 1990), also provide fundamental information on sedimentary evolution of the Nankai forearc.

The purpose of this chapter is thus to delineate the sedimentary facies evolution model of the Nankai trench and forearc based on a synthesis of drilling results and site surveys. Then we attempt to apply this model to the Shimanto Belt as a case study for calibration of the exhumation rate of the prism.

'Hill, L.A., Taira, A., Firth, J.V., et al., 1993. Proc. ODP, Sci. Results, 131: College Station, TX (Ocean Drilling Program).

${ }^{2}$ Ocean Research Institute, University of Tokyo, 1-15-1 Minamidai, Nakano, Tokyo 164, Japan.

\section{GEOLOGIC SETTINGS}

\section{Nankai Trough}

The Nankai Trough extends $700 \mathrm{~km}$ from the Suruga Trough, which marks a collision zone between the Izu-Bonin island arc and the Honshu arc, to the northern tip of the Kyushu-Palau Ridge (Fig. 1). The Nankai accretionary prism defined as the landward wedge of the Nankai Trough mainly consists of offscraped and underplated materials from the trough fill turbidites and the Shikoku Basin hemipelagic sediments. The Shikoku Basin, a backarc basin of the Izu-Bonin island arc, is situated in the northern corner of the Philippine Sea Plate, which is converging to the northwest or westnorthwest, based on fault plane mechanisms (Kanamori, 1971) and plate kinematics (Seno, 1977). Estimated values of the convergent rate vary from 1 to $2 \mathrm{~cm} / \mathrm{yr}$ (Ranken et al., 1984) to 3 to $4 \mathrm{~cm} / \mathrm{yr}$ (Seno, 1977).

Analysis of magnetic anomalies suggests multiple episodes of Shikoku Basin spreading during the late Oligocene to middle Miocene (Kobayashi and Nakada, 1978; Shih, 1980). The history of the opening is mainly divided into two episodes: east-west spreading during 27-19 Ma and north-south spreading during 14-12 Ma (e.g., Chamot-Rooke et al., 1987). The Kinan Seamount Chain, which is being subducted at this study area (Fig. 1), is interpreted to be formed by an episode of off-ridge volcanism and/or an expression of an aborted stage of seafloor spreading in the Shikoku Basin (Klein and Kobayashi, 1980; Chamot-Rooke et al., 1987).

The Nankai Trough off Shikoku is characterized by a broad, flat seafloor in water depths between 4500 and $4900 \mathrm{~m}$ (Fig. 2), and the trough floor is filled by a turbidite sequence overlying the Shikoku Basin hemipelagic mudstone. The cross section along the trough axis, however, shows considerable irregularities in the oceanic basement (Le Pichon et al., 1987). This suggests that the trench-filling process is closely controlled by basement relief, with a large variation in trench-fill thickness observed (Le Pichon et al., 1987). The turbidite sediments transported laterally along the trough axis from the Suruga 


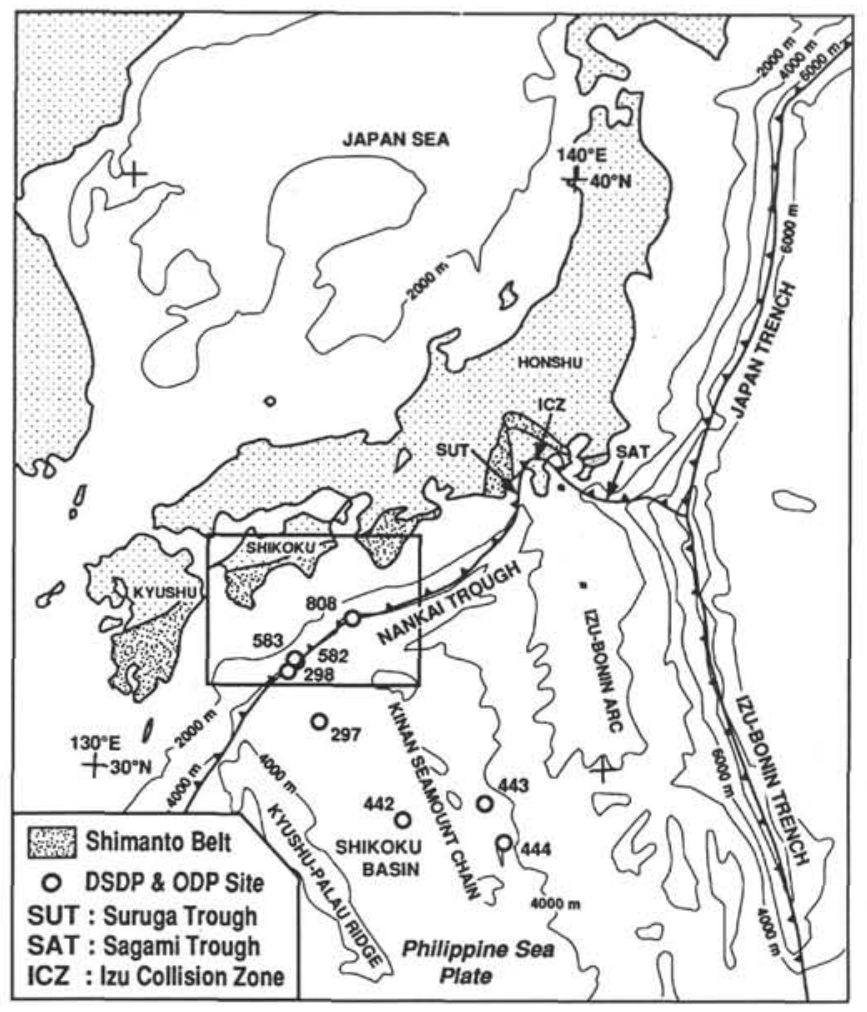

Figure 1. Location map showing the Nankai Trough, Shikoku Basin, and related physiographic features, and the DSDP-ODP drilling sites. The distribution of a Cretaceous-Tertiary accretionary prism, the Shimanto Belt, is also shown. The rectangle is the area shown in Figure 2.

Trough are interpreted to be the direct consequence of the Izu collision in Pliocene-Pleistocene times (Taira and Niitsuma, 1986).

Basically, four modes of sediment transportation processes dominate the trench to forearc region of the Nankai Trough: hemipelagic background sedimentation for the entire region except the shelf area, axial trench turbidites, coarse shelf clastics from the hinterlands of southwest Honshu and Shikoku, and volcanic ash mainly from Kyushu and the Izu-Bonin arc. The shelf sands are transported to several canyons that cross-cut the accretionary prism. Compared to axial transport of coarse clastics, the amount of canyon-fed sediments to the trough floor is subordinate (Taira and Niitsuma, 1986).

\section{Shimanto Belt}

The Nankai forearc grades landward to the older accretionary prism called Shimanto Belt. Extending from central Honshu to the Ryukyu Islands, the Cretaceous to Tertiary Shimanto Belt is about $1800 \mathrm{~km}$ along strike with a maximum width of $100 \mathrm{~km}$ and constitutes the largest structural element of the Japanese Islands. The belt represents one of the best-documented accretionary prisms in the world (Taira, Katto, et al., 1988; Taira, Byrne, and Ashi, 1992). It is composed of two main lithologies: a relatively coherent turbidite sequence and a highly deformed melange belt, most of the rocks being metamorphosed from zeolite to locally greenschist facies. These lithologies occur in a repeated fashion with systematic oceanward younging. The main component of the lithology, the turbidite facies, has been interpreted as an axial-transported trench-fill sequence. The melange zones include broken pieces of oceanic plate stratigraphy such as pillow lavas, pelagic cherts, and hemipelagic shale intermixed with outer trench fine-grained turbidites.
Overlying the unconformity are several exposures of cover sequences from Cretaceous to Tertiary age. They represent various depositional environments from slope basin to shelf/coastal zone. Among them, well-developed ones belong to middle Miocene forearc basin sequences that we consider as a main case study.

\section{DATA SOURCE}

One of the important data sources for this paper is the IZANAGI acoustic image. The IZANAGI seafloor imaging system includes 11to $12-\mathrm{kHz}$ acoustic backscattering measurement and a bathymetric mapping system in a single body towed at depths of $120 \mathrm{~m}$ or less at speeds up to $8 \mathrm{kt}$. The IZANAGI survey was carried out using the Shinsan Maru, operated by the Ocean Research Institute, University of Tokyo, in conjunction with Seafloor Survey International, K-Marine, and Sanyo Techno Marine, between 8 June and 23 June 1989. The $3.5-\mathrm{kHz}$ sub-bottom profiles were obtained simultaneously. The survey area covered both the Nankai Trough and the accretionary prism off Shikoku.

Closely spaced seismic reflection profiles have been obtained in the studied area by various organizations. All seismic reflection lines, including unpublished data, have been obtained during the past $10 \mathrm{yr}$ (e.g., Nasu et al., 1982; Leggett et al., 1985; Kaiko I Research Group, 1986; Taira et al., 1988; Moore et al., 1990). The bathymetry off Shikoku was provided by the SeaBeam map constructed during the Kaiko project in 1984 (see Le Pichon et al., 1987) and the IZANAGI data based on a phase-difference technique.

\section{SEDIMENTARY FACIES IN THE NANKAI FOREARC}

\section{Shikoku Basin Facies}

On DSDP legs, four sites, 297, 442, 443, and 444, were occupied by the Glomar Challenger in the Shikoku Basin (Karig, Ingle, et al., 1975; Klein, Kobayashi, et al., 1980). They provide a basic framework for stratigraphic evolution (Figs. 1 and 3). The Shikoku Basin can be roughly divided by the north-northwest-south-southeast trending Kinan Seamount Chain into two basins: the eastern Shikoku Basin and the western Shikoku Basin. The lithology of the Shikoku Basin sediments is dominated by hemipelagic mudstone intercalated by volcanic ash layers. It seems that the depth of the Shikoku Basin has been close to the carbonate compensation depth (CCD) throughout its evolution to the present (White et al., 1980). The hemipelagite thus shows a considerable variation in preservation of calcareous planktonic organisms. The basin-wide correlation of the history of CCD fluctuation has not yet been established.

The thickness variation and lithologic characteristics of the Shikoku Basin sediments indicate two dominant patterns: a general southward decrease of total sediment thickness and westward decrease of volcanic materials. As summarized by White et al. (1980), these patterns have been interpreted as the consequence of southward supply of terrigenous components from the mainland of the Japanese island arcs and the westward supply of volcanic materials from the Izu-Bonin arc. Thicker hemipelagite at Site 297 is the consequence of its landward proximity, and frequent ash intercalation at Sites 443 and 444 in the eastern basin can be interpreted as the consequence of proximity to the Izu-Bonin arc.

Site 808 drilled a 680 -m-thick Shikoku Basin hemipelagite sequence (Fig. 3). Although the lithology of the Shikoku Basin sequence at this site in general is similar to other drill sites, considerable variation in the various chronostratigraphic horizons are evident. The thickest Pliocene hemipelagite sequence occurs at Site 297, which is more distal than Site 808 with respect to the mainland. We interpret such variation as possibly due to some component of the hemipelagites being transported by clouds (plumes) of turbidity currents. Pliocene ponding of turbidity current plumes in the western Nankai Trough is also evident from the basal Pliocene turbidite intercalations 


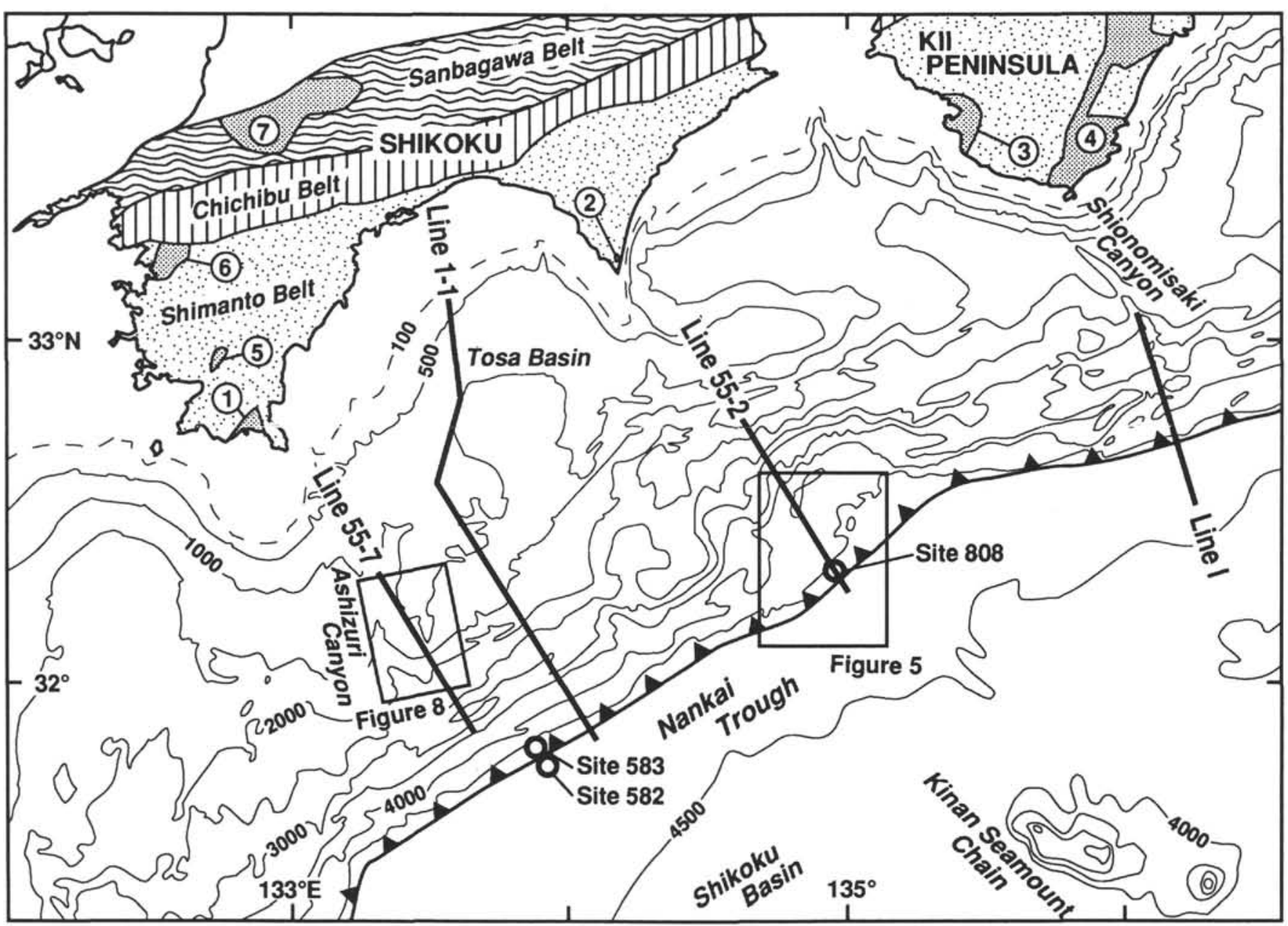

Figure 2. Close-up of the western part of the Nankai Trough and land geology discussed in this chapter. DSDP-ODP sites are also shown. Solid lines denote the location of seismic lines shown in Figures 6,8, and 9. Broken lines are referenced seismic lines used for general deduction of observation. Two boxes indicate the areas of the IZANAGI survey shown in Figures 5 and 8. The numbered shaded areas on the Shikoku and Kii Peninsulas designate the distribution of cover sequences: 1 = Miocene Misaki Group, 2 = Miocene Shijujiyama Formation, 3 = Miocene Tanabe Group, 4 = Miocene Kumano Group, 5 = Eocene Hirata Formation, 6 = Upper Cretaceous Uwajima Group, and 7 = Eocene Kuma Group lying on the Sanbagawa metamorphic belt.

at Site 297 (Karig, Ingle, et al., 1975). This turbidity current activity at Site 297 is not evident at other sites.

A thick tuffaceous layer at the base of the Site 808 Shikoku Basin sequence is intriguing. The origin of this layer has not yet been fully documented, but likely originated from the subduction of an active spreading center of the Shikoku Basin at about $15 \mathrm{Ma}$ (Taira, Hill, Firth, et al., 1991).

\section{Trench Facies}

Four DSDP-ODP sites provide information on trench sedimentation (Fig. 3). Site 582 was drilled at the undeformed trench wedge and Sites 298, 583, and 808 were drilled in the toe of the wedge (Karig, Ingle, et al., 1975; Kagami, Karig, Coulbourn, et al., 1986; Taira, Hill, Firth, et al., 1991). Recovery at Site 298 was very low due to spot coring, so information on the sedimentary facies is very limited. Sites 582 and 808 show a similar pattern of sedimentation but Site 808 provides better information due to improved core recovery (Taira et al., 1992)

At Site 808 , the Nankai trough-fill sequence starts from the transition zone lithology (hemipelagite/ash/silty turbidites, Unit III) and grades upward to the lower thin-bedded turbidites (Unit IIc and $\mathrm{Ilb}$ ) and to the upper thick-bedded, coarser-grained turbidites
(Unit IIa) (Fig. 4). This coarsening-upward megacycle is the first documentation of axial trench-fill cycle from a modern trench. The origin of the first-order coarsening-upward cycle in the trench can best be explained by the fact that the axial channel positions itself near the deformation front. As documented by Hsü and Ryan (1973), trenches tend to tilt landward as the plate progressively bends and subducts. The trench wedge also tends to be uplifted at the deformation front due to faulting and ductile deformation (Moore et al., 1990). Consequently, the seaward trench floor at the margin of deformation becomes the depression that turbidity currents choose as the main course of flow.

The massive sand beds up to $10 \mathrm{~m}$ in thickness in Unit IIa also document the existence of thick-bedded massive sandstone units in deep trench environments that are so commonly observed in ancient accretionary prisms (e.g., Taira, Katto, et al., 1988),

Site 808 logging data, although covering a very short interval (about $80 \mathrm{~m}$ ), cross an important facies transition from lower axial trench wedge to upper axial trench wedge (Unit IIb to IIa). The data provide insight into the nature of second-order cyclicity in turbidity current sedimentation. The cycles are dominated by a fining-upward trend sometimes with a basal subordinate coarsening-upward part. The fining-upward cycles of the order of $10 \mathrm{~m}$ thick are common in this interval. Similar cycles have also been reported from the 


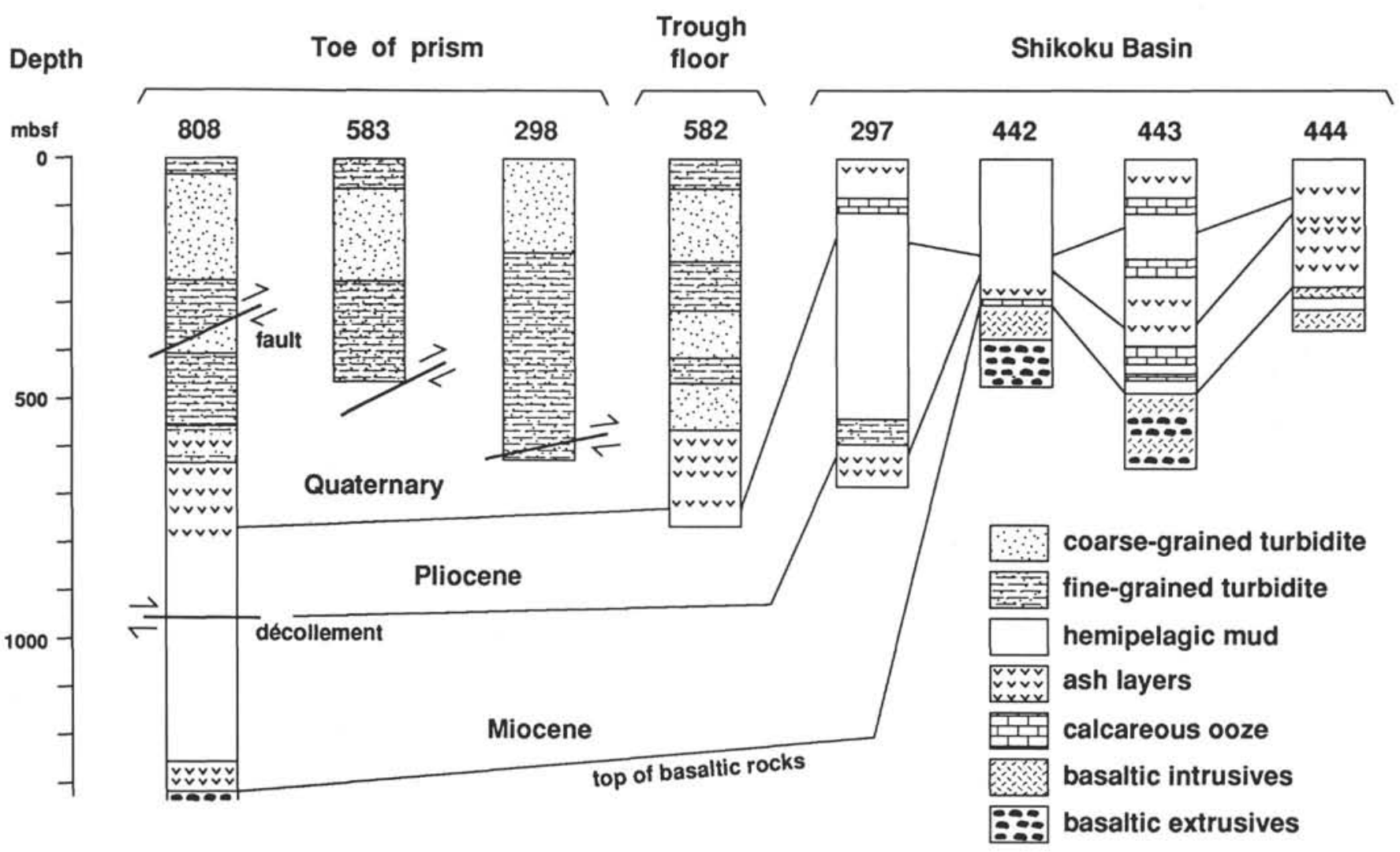

Figure 3. Compilation of stratigraphy of DSDP-ODP drilling sites from Shikoku Basin to Nankai accretionary prism toe.

Shimanto Belt (Taira, Byrne, and Ashi, 1992). The origin of secondorder fining-upward cycles in the axial transport system can be regarded either as: (1) single-event turbidity currents from vigorous flow to diminishing flow; (2) oscillating and decaying flows within the trench (Pickering et al., this volume), or (3) systematic migration of the axial channel. The observation that both the modern and ancient trench-fill turbidite wedges are composed of a systematic architecture of a first-order coarsening-upward cycle that is then made of a group of second-order cycles suggests that a common depositional process closely related to the nature of the axial trench system is responsible for these cycles. Thus, the hypothesis we prefer is the tectono-sedimentary control of the axial channel migration.

The Nankai Trough floor near Site 808 shows a flat surface with no deeply dissected or levee-fenced channels such as are common in the eastern part of the trough as seen in IZANAGI images (Fig. 5). Instead, 3.5-kHz sub-bottom profiling (Taira, Katto, et al., 1988, fig. 29) shows a shallow channel (less than $10 \mathrm{~m}$ relief), which indicates that less-confined flows dominate in this part of the trough. If this is the case, a large flow tends to lay a sheet sand layer in the trough, temporarily suppressing the channel topography. Between the large events, the channel is gradually built near the deformation front due to the above-stated tectonic control. The process of channel formation tends to confine smaller flow away from the overbank part of the trough, producing a fining-upward cycle of turbidite sedimentation between the large events.

\section{Prism Toe Sedimentary Facies}

Sites 583 and 808 provide information on the sedimentary nature of the surface veneer of the prism toe region. Site 583 shows a fining-upward trend from the coarse axial turbidites to "overbank" finer-grained, lowermost-slope turbidite cover (Taira and Niitsuma, 1986). A similar lithology, but internally deformed with recumbent folds and chaotic bedding was encountered in the uppermost layers of Site 808. This facies was interpreted as lower slope apron facies (Unit I) (Taira, Hill, Firth, et al., 1991). The IZANAGI sidescan sonar image (Fig. 5) shows the existence of a small trench fan near Site 808 that was apparently fed by cannibalism of a part of the accretionary prism. The seismic reflection profiles also reveal that a part of the hanging wall anticline is truncated (Moore et al., 1990). Thus it is apparent that unstable seafloor conditions exist in the toe region due to active faulting and steep fault scarp within partly lithified sediments.

\section{Slope Basin Facies}

No drilling data are available from the landward slope region of the Nankai Trough. The interpretation of sedimentary facies is based mainly on swath mapping, $3.5-\mathrm{kHz}$ sub-bottom profiling, and seismic reflection profiling, and partly supported by piston coring, dredging, and underwater photography. There are two types of sedimentation patterns in the slope region: tectonic controlled and canyon controlled.

\section{Tectonic-controlled Slope Sedimentation}

Ashi and Taira (in press) classified the accretionary prism slope into three zones. Zone I is the active faulting zone at the toe, Zone II is the internal deformation zone with relatively minor surface deformation, and Zone III is the faulting zone in the upper slope. Zone I coincides with the toe sediment facies which is described above. The IZANAGI image (Fig. 5) and seismic profile (Fig. 6), together with piston coring (Taira et al., 1988), show that the surface hemipelagic veneer suffers minor deformation in Zone II with less disturbance by slumping and debris-flow activity. In Zone III, the IZANAGI image shows tilting and folding of slope basins, and a large-scale collapse of slope, producing a field of slumping and debris-flow deposits (Figs. 6, 7, and 8). The area of slope failure, slumping, and debris-flow 


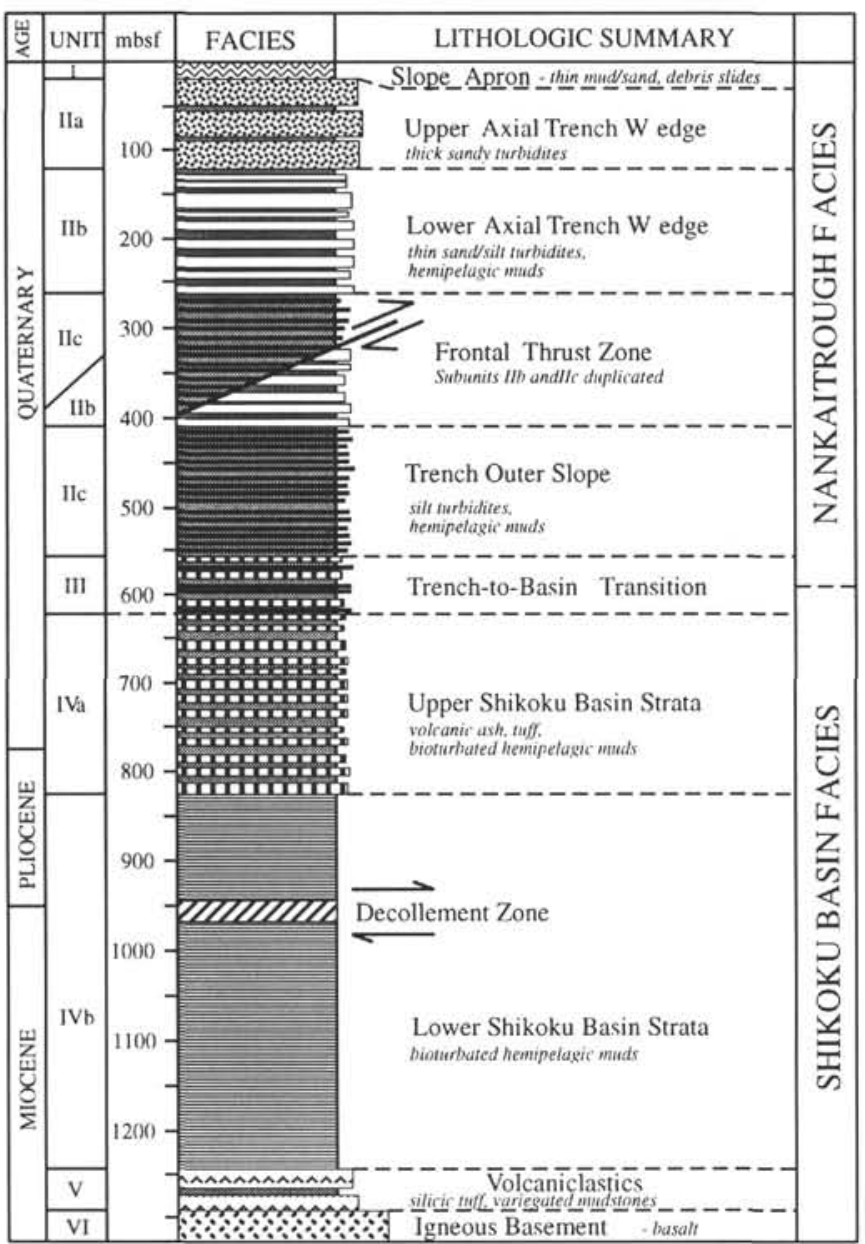

Figure 4. Stratigraphy and sedimentary facies interpretation of Site 808, Leg 131.

deposits is identified mainly based on the IZANAGI image and 3.5$\mathrm{kHz}$ records. For example, in the Ashizuri Canyon area, a large area of slope failure (at least $20 \mathrm{~km}$ by $30 \mathrm{~km}$ ) with submarine slide deposits is recognized (Fig. 8). Such slide deposits can be composed of blocks and fragments of consolidated older accretionary prism materials (olistostromes) as they are apparently exposed on the seafloor.

The interpretation of sedimentary facies evolution in the slope region indicates the following trend: soft-sediment slump deposits in Zone I and hemipelagic cover in Zone II, which is progressively deformed, and then overlain by large olistostromes in Zone III.

\section{Canyon-controlled Slope Sedimentation}

When a large submarine canyon cuts across the accretionary complex, the canyon-controlled sedimentation dominates on the slope region. The best example can be documented at the Shionomisaki Canyon where the canyon cuts from the forearc basin to the trench floor (see Fig. 2 for location). Between the anticlinal ridges of the accretionary prism, the mid-slope basins are filled by canyontransorted materials and are progressively tilted and deformed into a syncline (Fig. 9). In these cases, we infer that the slope basins are filled by coarser clastics transported through the canyon. As the coarse clastics dominate from the trench slope break down to the trench floor, the steady-state hemipelagic accumulation within these slope basins is overwhelmed near canyon environments. A possible ancient analogue in the Tertiary Shimanto Belt (middle Miocene Shijujiyama Formation) is discussed later.

\section{Forearc Basin}

The seismic profiling (Fig. 10) and surface sampling indicate four major sedimentary facies within the forearc basin: canyon-fill facies, basin plain, slope apron facies, and progradational shelf delta facies (Okuda and Honza, 1988; Okamura, 1989). The canyon-fill facies occurs where a large canyon feeds into the forearc basin such as Shionomisaki Canyon. The activity of the canyon seems to be related to sea-level changes. Canyons feed the shelf-derived coarse clastics from the delta front to the lower trench-landward slope, often bypassing the basin plain. The basin plain seems to be dominated by mud with intercalation of turbidites, the main constituents of which are pumices, plant debris, and microfossils (Okamura et al., 1987). The basinal mud facies differs in lithology from the Shikoku Basin and slope hemipelagites in that it is much richer in calcareous fossils and plant debris. The slope apron facies are composed of slope-derived, numerous gully-transported, clastic/foraminifer-rich sediments, and the relative abundance of each component may change according to sea-level fluctuation (Okamura, 1989). The progradational deltas are composed of several unconformity-bounded sequences. The details of the sequence stratigraphy is not within the scope of this chapter; instead, we emphasize that the basin/slope apron facies is basically overlain by progradational, presumably coarsening-upward, shelf-tocoastal facies.

The lower boundary of the forearc basin sequence can be analyzed by seismic reflection profiles (Fig. 7). The profiles show the transition from the upper slope debris flow and slump beds (olistostromes) to the base of forearc basin sediments. The forearc basin sequence starts to develop on the olistostrome facies that lies unconformably on a complex of deformed lower slope deposits and older accretionary prism. This submarine unconformity between the deformed accretionary prisms/lower slope sediment complex and the base of forearc basin sequence should provide an important constraint to the uplift rate of accretionary prism.

\section{Sedimentary Facies Evolution Model}

In Figure 11, we summarize the above description and discussion. In this figure we emphasize two coarsening-upward cycles in the forearc: ocean floor-to-trench environments and forearc basin plainto-shelf environments. It should be noted that this sedimentary facies model can be applied to a particular setting of forearc: a combination of dominant axial turbidite transport system in trench, hemipelagic background sedimentation near trench slopes and delta progradation in forearc basin slopes.

If such facies can be identified in ancient forearcs, the facies analyses not only give information on the overall sedimentary setting but should also provide information on the growth rate of the prism. In the next section we present briefly the application of such a facies model to the Shimanto Belt and discuss preliminary implications for the growth of an accretionary prism as a case study.

\section{APPLICATION TO THE SHIMANTO BELT}

\section{Facies Identification in the Shimanto Belt}

\section{Slope Basin Facies}

In the Shimanto Belt two types of hemipelagic sediments occur: one is a finer-grained, deformed, and older (compared to trench-fill turbidite) hemipelagite and the other is a siltier, less deformed, more laterally continuous and younger hemipelagite. The age-structural relationship apparently suggests that the former is the ocean-floor hemipelagite and the latter is the slope hemipelagite. 


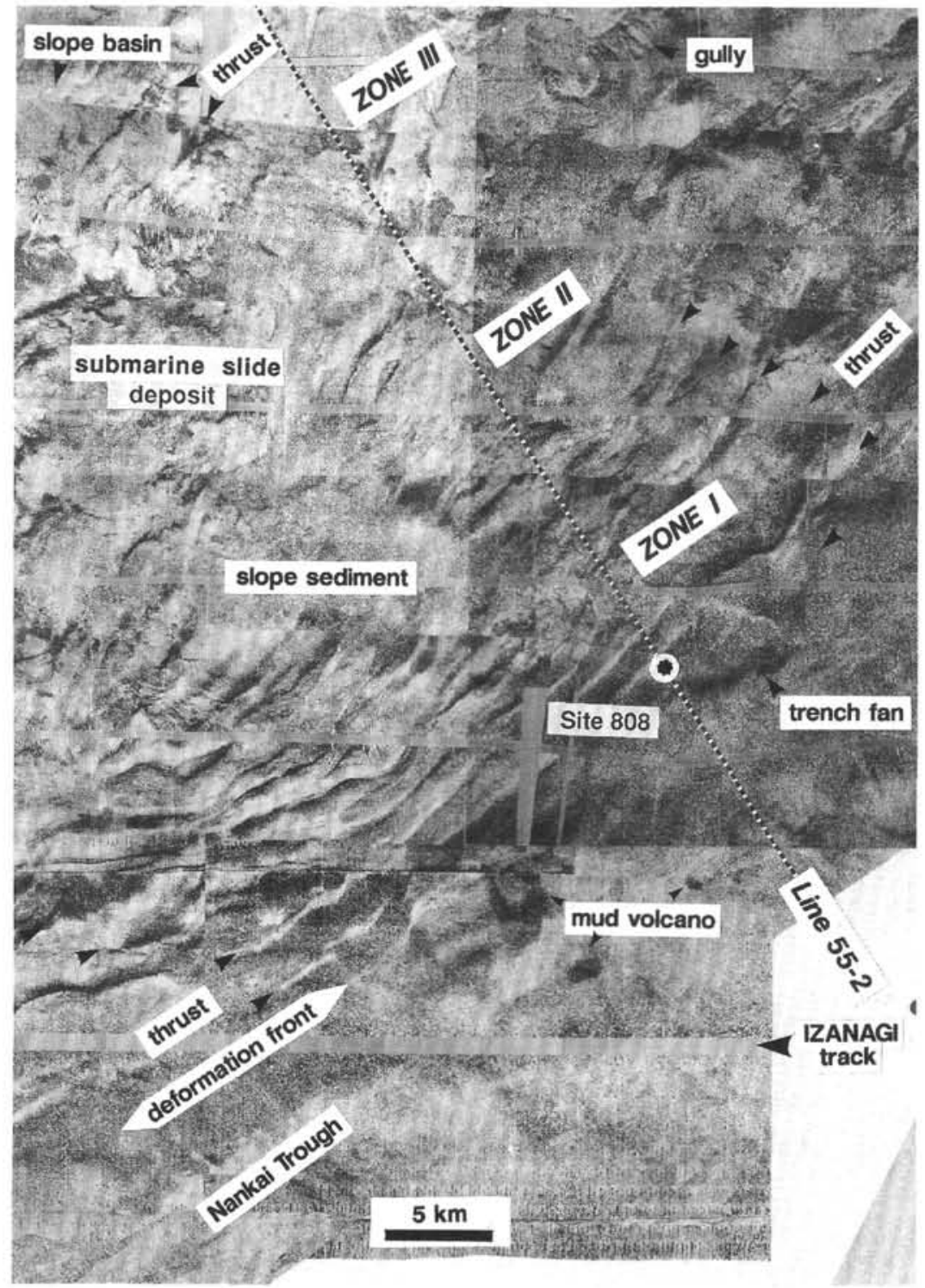

Figure 5. IZANAGI seafloor backscattering mosaic near Site 808. Interpretation of various features and structural zones (see text) are indicated. North is toward the top of the figure.

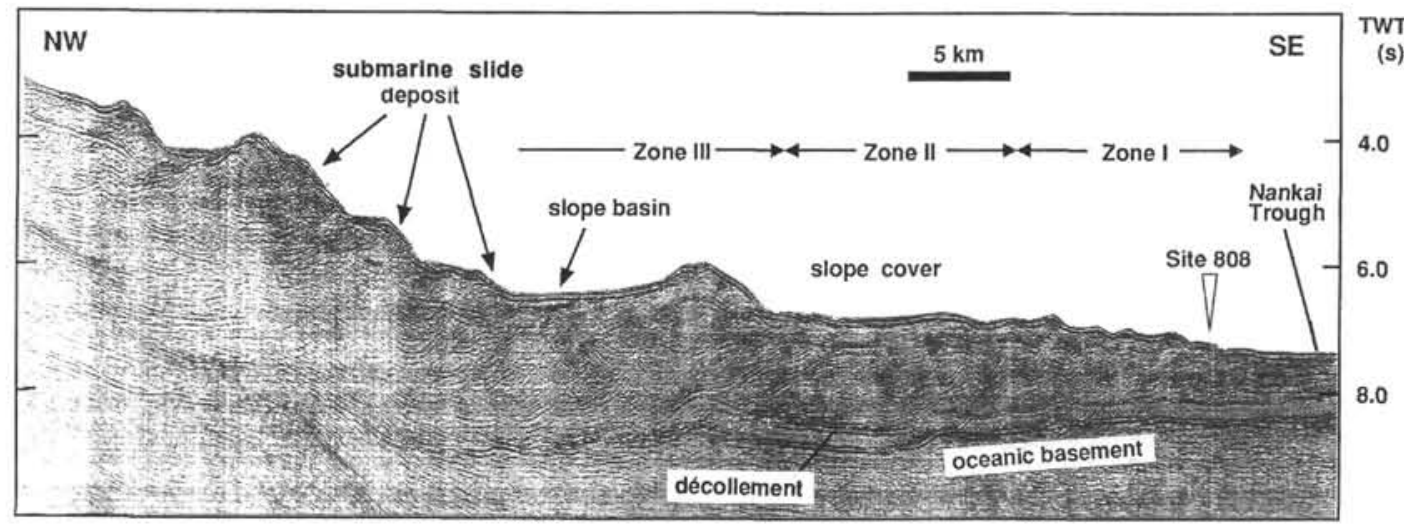

Figure 6. Multichannel seismic reflection profile (JAPEX line 55-2) across the Nankai prism toe (near Site 808) to the upper slope region. Structural zones (see text) are indicated. 

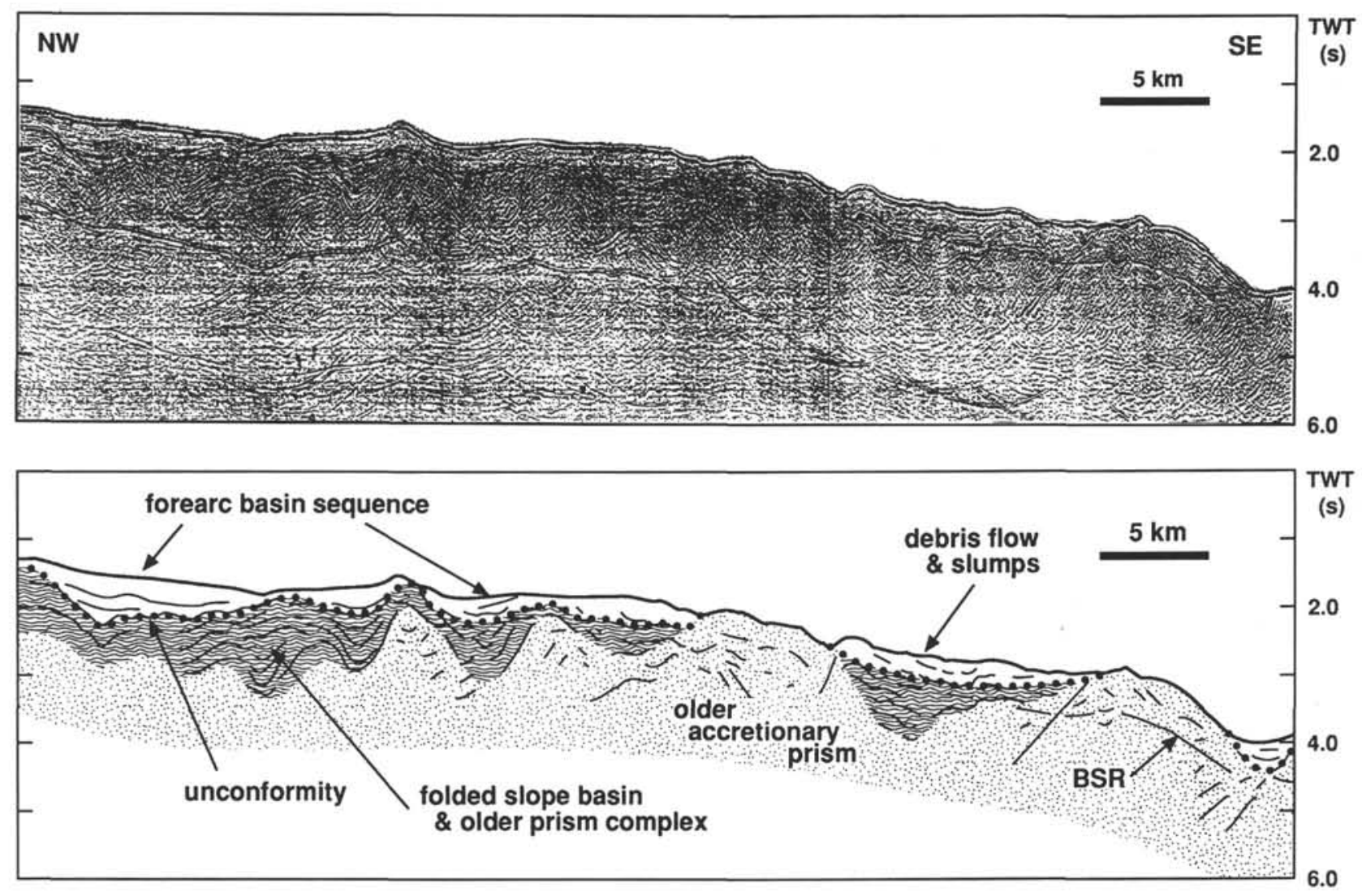

Figure 7. Multichannel seismic reflection profile (JAPEX Line 55-7) and interpretation at the trench slope break area near Ashizuri Canyon. Note a submarine unconformity between the deformed slope basin and older accretionary prism complex, and upper slope debris-flow and slump deposits (olistostrome), which is identified on the basis of an IZANAGI image (Fig. 8) and 3.5-kHz records. The olistostrome is then progressively covered by a forearc basin sequence. The age of this unconformity is unknown.

The lower Miocene Shijujiyama Formation (Fig. 2) occupies a unique tectono-lithologic setting. The formation lies on the deformed upper Oligocene and lower Miocene accretionary prism and starts from basal thin muddy facies to coarse massive sand facies that bear molluscan fauna (Taira, Katto, et al., 1988). Except for the fact that the basal unit contains volcanic materials that have been interpreted as a consequence of active spreading center subduction (Hibbard et al., in press), the formation shows similarities to the canyon-controlled slope basin of the Shionomisaki area. A similar sandstonedominated slope facies, the Hirata Formation, is also recognized in the Eocene Shimanto Belt (Fig. 2).

\section{Forearc Basin Facies}

The lower Miocene Misaki Group (Fig. 2) provides an excellent example for the upper-slope-to-forearc-basin facies evolution. It starts from basal olistostrome, basin mud facies to shelf and tidal sand facies, showing a clear coarsening- and shallowing-upward cycle (Katto and Taira, 1979). Similar sequences, although with variations in relative development of each facies, can be observed in the lower Miocene sequence in Kii Peninsula (Editorial Committee of KINKI, 1987). Mud diapirs in the lower Miocene forearc sequence from this region also provide excellent ancient analogies to the modern forearc.

In the upper Cretaceous Uwajima Group (Fig. 2) that overlies the lower Cretaceous accretionary prism, the basin facies includes huge slides of shelf facies. Similar examples are also found in Tertiary sequences in Kyushu (Sakai, 1987). Although we have not identified such slides in the slope area of the modern Nankai forearc basins, it is likely that they occur commonly in both modern and ancient settings.

\section{Identification of Unconformity}

The facies model we present suggests that regional scale unconformities occur in the basal part of the forearc basin facies. The age difference across this unconformity is the first-order data for growth and exhumation of accretionary prisms.

In Table 1 we list the examples of the nature of unconformities observed from the lower Miocene cover sequences of the Shimanto Belt. From the table it is evident the minimum duration of each hiatus falls within a small range of values about $5 \mathrm{~m}$.y. As the youngest age of the underlying sequence includes the age for trench deposits, the data suggest that it took $5 \mathrm{~m}$.y. from sedimentation at trench to exposure at the upper slope. A simple implication of this is that the underlying sediment was gradually uplifted and finally reached the point of unconformity, whatever the trajectory of the sediment was within the prism. Assuming the bathyal depth of unconformity from benthic foraminifer data (about $1000 \mathrm{~m}$ ) and trench depth was $6 \mathrm{~km}$ (top of the Shikoku Basin oceanic crust), we infer that the vertical uplift of the trench sediment was $5 \mathrm{~km}$. The $5-\mathrm{km}$ uplift in $5 \mathrm{~m} . \mathrm{y}$. indicates a rate of $1 \mathrm{~km} / \mathrm{m} . \mathrm{y}$.

We compare the data with other independent measurements of the exhumation rate: exhumation of Sanbagawa Belt and fission track dating. To the north of the Shimanto Belt is a metamorphosed accretionary complex under high pressure and lower temperature conditions called the Sanbagawa Belt (Fig. 2). The age of metamorphism 
is 85 to $75 \mathrm{Ma}$ (Takasu and Dallmeyer, 1990, suppose $80 \mathrm{Ma}$ as mean age) and is overlain by the middle Eocene shallow marine-terrestrial Kuma Group (assume $50 \mathrm{Ma}$ as basal age). Assuming the peak metamorphism took place at $30 \mathrm{~km}$ depth, the mean exhumation rate is $1 \mathrm{~km} / \mathrm{m}$.y.

The fission track dating of annealed sphere and zircon included in the Tertiary Shimanto sedimentary rocks suggests that they are uplifted from the apatite annealing zone $\left(60^{\circ}\right.$ to $\left.120^{\circ} \mathrm{C}\right)$ in about $10 \mathrm{~m}$.y. (Hasebe et al., in press). Assuming the present thermal structure, this gives an exhumation rate of about a $0.5 \mathrm{~km} / \mathrm{m}$.y.

It can also be pointed out the rate of uplift calibrated from the height-age relationship of coastal terraces of Shikoku shows range of about $2 \mathrm{~km} / \mathrm{m}$.y. (Yoshikawa et al., 1964). Because this uplift rate is probably related to active seismic faulting, this value seems to give a peak maximum value. All of these data show a similar magnitude of vertical movement rate and we suggest that over a long period, $0.5-1 \mathrm{~km} / \mathrm{m} . \mathrm{y}$. is a reasonable estimate.

The exhumation of an accretionary prism at the trench slope break is probably controlled by underplating of materials (Leggett et al., 1985; Taira et al., 1988; Moore et al., 1990). As shown in Taira, Katto, et al. (1988), the incoming sediment thickness and convergence rate are not very different throughout the evolution of the ShimantoNankai accretionary prisms. Therefore, we suggest that the exhumation rate presented in this chapter $(0.5-1 \mathrm{~km} / \mathrm{m}$.y.) can be considered a "standard" value for this kind of tectono-sedimentary setting and can be used as a parameter appropriate for testing the mass-balance model for growth of the Shimanto-Nankai accretionary prism.

\section{CONCLUSION}

The sedimentary facies model of the Nankai forearc proposed in this chapter is composed of two parts: the ocean floor-trench-lower slope sedimentary facies evolution and the upper-slope-to-forearcbasin sedimentary facies evolution. The former starts from the basal pelagic and hemipelagic mudstone to coarsening-upward trench turbidite sequence covered by slope apron slumps and lower slope hemipelagic mudstone. This assemblage is progressively faulted and folded into a consolidated accretionary prism that is then fractured and faulted in the upper slope region. Massive failure of the seafloor in the upper slope region produces olistostrome deposits that contain lithified blocks derived from an older accretionary prism dispersed in mud matrix. The contact between the older accretionary prism and the upper slope olistostrome is a submarine unconformity that is the first stratigraphic evidence for the exhumation of an older prism from the seafloor. The olistostrome beds are then overlain by forearc basinplain mudstone and turbidites which are progressively covered by coarsening-upward delta-shelf sequences.

An application of the forearc facies model to the Shimanto Belt was attempted to ensure feasibility of this model. Several characteristic lithologies observed in the Shimanto Belt can be interpreted with it. The lower slope hemipelagic mudstone sequence, slope sandstone deposits, and basal olistostrome of coarsening-upward basin-to-shelf sequence are interpreted with this model, or previous interpretations are confirmed based on this model. The unconformities found in the Shimanto Belt were evaluated in order to provide an estimate for the exhumation rate of the prism. Comparison with independent measurements of exhumation rate provides about $1 \mathrm{~km} / \mathrm{m}$.y. vertical growth of the prism.

The Nankai forearc represents a typical example of the following sedimentary settings: (1) domination of an axial trench transport system in coarse clastics, (2) relatively uniform hemipelagic sedimentation outward and inward of the trench environment, and (3) clastic sedimentation only in the shelf area of the forearc basin except the deep, dissected canyons. The Nankai forearc is also unique because it is relatively starved of volcanic input. Nevertheless, this facies model can be easily expanded and modified for further variation and will provide a useful basis for interpretation of ancient accretionary prisms.

\section{ACKNOWLEDGMENT}

We express our appreciation to K. Suyehiro, H. Tokuyama, S. Kuramoto, and KDD, Sanyo, and SSI companies for their cooperation in obtaining the field data. Our appreciation is extended to JAPEX for the use of their seismic profiles. A. Taira acknowledges the shipboard scientific members of Leg 131 for productive discussions during and after the cruise. Comments by D. Cowan and Y. Ogawa are greatly appreciated. We also appreciate the help in manuscript preparation provided by Chizuru Kinoshita and Tomiko Kanehara.

\section{REFERENCES}

Aoki, Y., Tamano, T., and Kato, S., 1982. Detailed structure of the Nankai Trough from migrated seismic sections. In Watkins, J.S., and Drake, C.L. (Eds.), Studies in Continental Margin Geology. AAPG Mem., 34:309-322.

Ashi, J., and Taira, A., in press. Structures of the Nankai accretionary prism as revealed from IZANAGI sidescan imagery and multichannel seismic reflection profiling. Island Arc.

Chamot-Rooke, N., Renard, V., and Le Pichon, X., 1987. Magnetic anomalies in the Shikoku Basin: a new interpretation. Earth Planet. Sci. Lett. $83: 214-228$

Editorial Committee of KINKI, 1987. KINKI. In Nakazawa, K., Ichikawa, K., and Itihara, M. (Eds.), Regional Geology of Japan (Pt. 6): Tokyo (Kyoritsu Shuppan).

Hasebe, N., Tagami, T., and Nishimura, S., in press. Evolution of the Shimanto complex: a fission-track thermochronologic study. In Underwood, M.B. (Ed.), Thermal Evolution of the Tertiary Shimanto Belt, Southwest Japan. an Example of Ridge-trench Interaction. Spec. Pap.-Geol. Soc. Am.

Hibbard, J.P., Karig, D.E., and Taira, A., in press. Anomalous structural evolution of the Shimanto accretionary prism at Murotomisaki, Shikoku Island, Japan. Island Arc.

Hsü, K.J., and Ryan, W.B.F., 1973. Summary of the evidence for extensional and compressional tectonics in the Mediterranean. In Ryan, W.B.F., Hsü, K.J., et al., Init. Repts. DSDP, 13: Washington (U.S. Govt. Printing Office), 1011-1019.

Kagami, H., Karig, D.E., Coulbourn, W.T., et al., 1986. Init. Repts. DSDP, 87: Washington (U.S. Govt. Printing Office).

Kaiko I Research Group, 1986. Taira, A., and Tokuyama, H. (Eds.), Topography and Structure of Trenches Around Japan-Data Atlas of FrancoJapanese Kaiko Project, Phase I: Tokyo (Univ. of Tokyo Press).

Kanamori, H., 1971. Faulting of the Great Kanto earthquake of 1923 as revealed by seismological data. Tokyo Daigaku Jishin Kenkyusho tho [Bull. Earthquake Res. Inst., Univ. Tokyo], 49:13-18.

Karig, D.E., Ingle, J.C., et al., 1975. Init. Repts. DSDP, 31: Washington (U.S. Govt. Printing Office).

Kato, S., Sato, T., and Sakurai, M., 1983. Multi-channel seismic reflection survey in the Nankai, Suruga and Sagami Troughs. Rep. Hydrographic Res., 18.

Katto, J., and Taira, A., 1979. The Misaki Group (Miocene), south-western Shikoku. Kochi Daigaku Gakujutsu Kenkyu Hokoku [Res. Rept. Kochi Univ.], 27:165-180.

Klein, G. deV., Kobayashi, K., et al., 1980. Init. Repts. DSDP, 58: Washington (U.S. Govt. Printing Office).

Kobayashi, K., and Nakada, M., 1978. Magnetic anomalies and tectonic evolution of the Shikoku interarc basin. J. Phys. Earth, 26:391-402.

Leggett, J.K., Aoki, Y., and Toba, T., 1985. Transition from frontal accretion to underplating in a part of the Nankai Trough accretionary complex off Shikoku (SW Japan) and extensional features on the lower trench slope. Mar. Pet. Geol., 2:131-141.

Le Pichon, X., Iiyama, T., Chamley, H., Charvet, J., Faure, M., Fujimoto, H., Furata, T., Ida, Y., Kagami, H., Lallemant, S., Leggett, J., Murata, A., Okada, H., Rangin, C., Renard, V., Taira, A., and Tokuyama, H., 1987. The eastern and western ends of Nankai Trough: results of Box 5 and Box 7 Kaiko survey. Earth Planet. Sci. Lett., 83:199-213.

Moore, G.F., Shipley, T.H., Stoffa, P.L., Karig, D.E., Taira, A., Kuramoto, S., Tokuyama, H., and Suyehiro, K., 1990. Structure of the Nankai Trough

\footnotetext{
* Abbreviations for names of organizations and publication titles in ODP reference lists follow the style given in Chemical Abstracts Service Source Index (published by American Chemical Society).
} 
accretionary zone from multichannel seismic reflection data. J. Geophys. Res., 95:8753-8765.

Nasu, N., et al., 1982. Multi-channel Seismic Reflection Data across Nankai Trough. IPOD-Japan Basic Data Series, 4. Ocean Res. Inst., Univ. of Tokyo.

Okamura, Y., 1989. Multi-layered progradational sequences in the shelf and shelf slope of the southwest Japan forearc. In Taira, A., and Masuda, F. (Eds.), Sedimentary Facies in the Active Plate Margin: Tokyo (Terra Sci. Publ.), 295-317.

Okamura, Y., Kisimoto, K., Murakami, F., and Joshima, M., 1987. Geological map of Tosa Bay. Geol. Surv. Jpn., Mar. Geol. Map Ser, 29 (scale 1:200,000).

Okuda, Y., and Honza, E., 1988. Tectonic evolution of the Seinan (SW) Japan fore-arc and accretion in the Nankai Trough. Mod. Geol., 12:411-434.

Pickering, K.T. Hiscott, R.N., and Hein, F.J., 1989. Deep Marine Environments: Clastic Sedimentation and Tectonics: London (Unwin Hyman).

Ranken, B., Cardwell, R.K., and Karig, D.E., 1984. Kinematics of the Philippine Sea Plate. Tectonics, 3:555-575.

Sakai, H., 1987. Origin of the Misaki Olistostrome Belt and re-examination of the Takachiho Orogeny. J. Geol. Soc. Jpn., 93:945-961.

Seno, T., 1977. The instantaneous rotation of the Philippine Sea plate relative to the Eurasian plate. Tectonophysics, 42:209-226.

Shih, T.C., 1980. Magnetic lineations in the Shikoku Basin. In Klein, G. deV., and Kobayashi, K., et al., Init. Repts. DSDP, 58: Washington (U.S. Govt. Printing Office), 783-788.

Taira, A., Byrne, T., and Ashi, J., 1992. Photographic Atlas of an Accretionary Prism: Geologic Structures of the Shimanto Belt, Japan: Tokyo (Univ. of Tokyo Press).

Taira, A., Hill, I., Firth, J., Berner, U., Brückmann, W., Byrne, T., Chabernaud, T., Fisher, A., Foucher, J.-P., Gamo, T., Gieskes, J., Hyndman, R., Karig, D., Kastner, M., Kato, Y., Lallement, S., Lu, R., Maltman, A., Moore, G., Moran, K., Olaffson, G., Owens, W., Pickering, K., Siena, F., Taylor, E., Underwood, M., Wilkinson, C., Yamano, M., and Zhang, J., 1992. Sedi- ment deformation and hydrogeology of the Nankai accretionary prism: synthesis of shipboard results of ODP Leg 131. Earth Planet. Sci. Lett., 109:431-450.

Taira, A., Hill, I., Firth, J.V., et al., 1991. Proc. ODP, Init. Repts., 131: College Station, TX (Ocean Drilling Program).

Taira, A., Katto, J., Tashiro, M., Okamura, M., and Kodama, K., 1988. The Shimanto Belt in Shikoku, Japan - evolution of Cretaceous to Miocene accretionary prism. Mod. Geol., 12:5-46.

Taira, A., and Niitsuma, N., 1986. Turbidite sedimentation in the Nankai Trough as interpreted from magnetic fabric, grain size, and detrital modal analyses. In Kagami, H., Karig, D.E., Coulbourn, W.T., et al., Init. Repts. DSDP, 87: Washington (U.S. Govt. Printing Office), 611-632.

Taira, A., and the Scientific Members of the Expedition, 1988. Preliminary Reports of the Hakuho-Maru Cruise KH86-5. Ocean Res. Inst., Univ. of Tokyo.

Takasu, A., and Dallmeyer, R.D., $1990 .{ }^{40} \mathrm{Ar} /{ }^{39} \mathrm{Ar}$ mineral age constraints for the tectonothermal evolution of the Sambagawa metamorphic belt, central Shikoku, Japan: a Cretaceous accretionary prism. Tectonophysics, 185:111-139.

White, S.M., Chamley, H., Curtis, D., Klein, G. deV., Mizuno, A., and Fountain, D.M., 1980. Sediment synthesis: Deep Sea Drilling Project Leg 58, Philippine Sea. In Klein, G. deV., Kobayashi, K., et al., Init. Repts. DSDP, 58: Washington (U.S. Govt. Printing Office.), 963-1013.

Yoshikawa, T., Kaizuka, S., and Ota, Y., 1964. Mode of crustal movement in the Late Quaternary on the southwestern coast of Shikoku, southwestern Japan. Geogr. Rev., 37:627-648.

\section{Date of initial receipt: 27 May 1992 \\ Date of acceptance: 21 October 1992 \\ Ms 131SR-136}

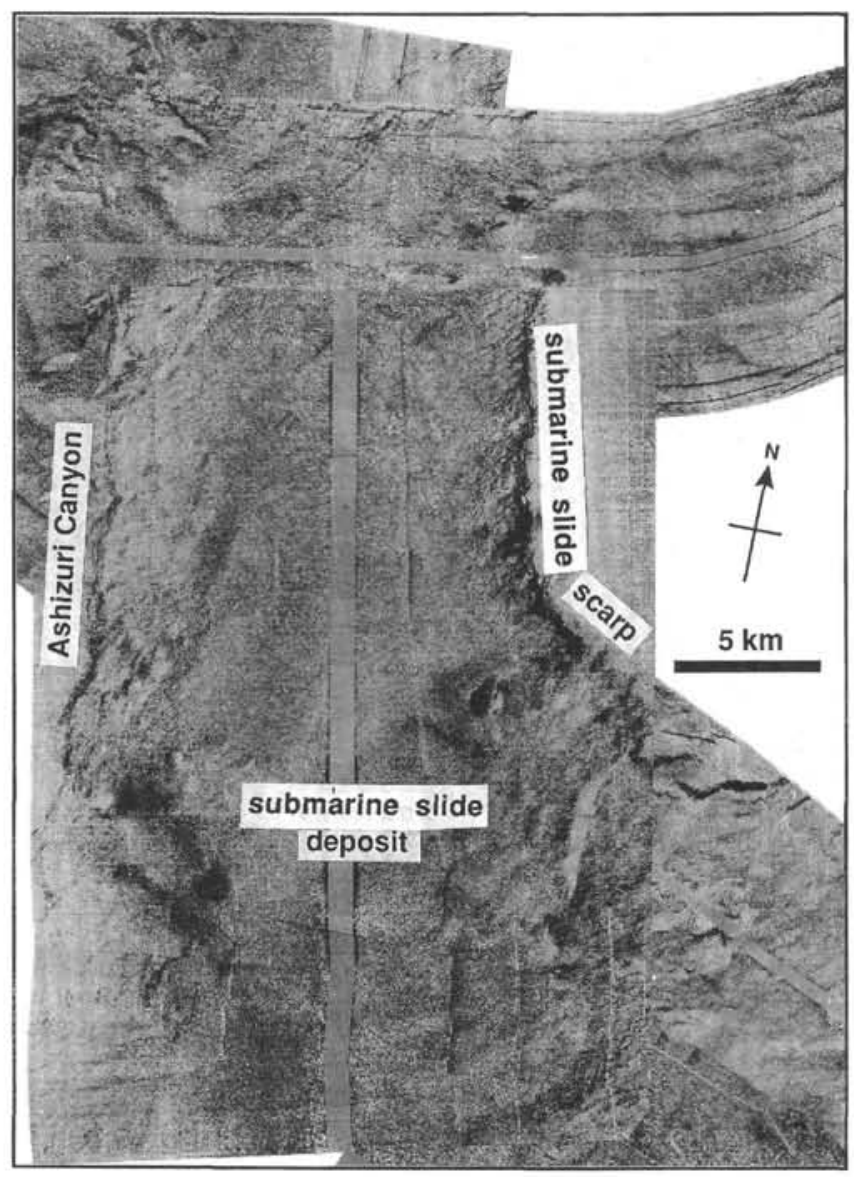

Figure 8. IZANAGI seafloor backscattering mosaic of the upper slope region near Ashizuri Canyon. Note a large slope failure feature. 


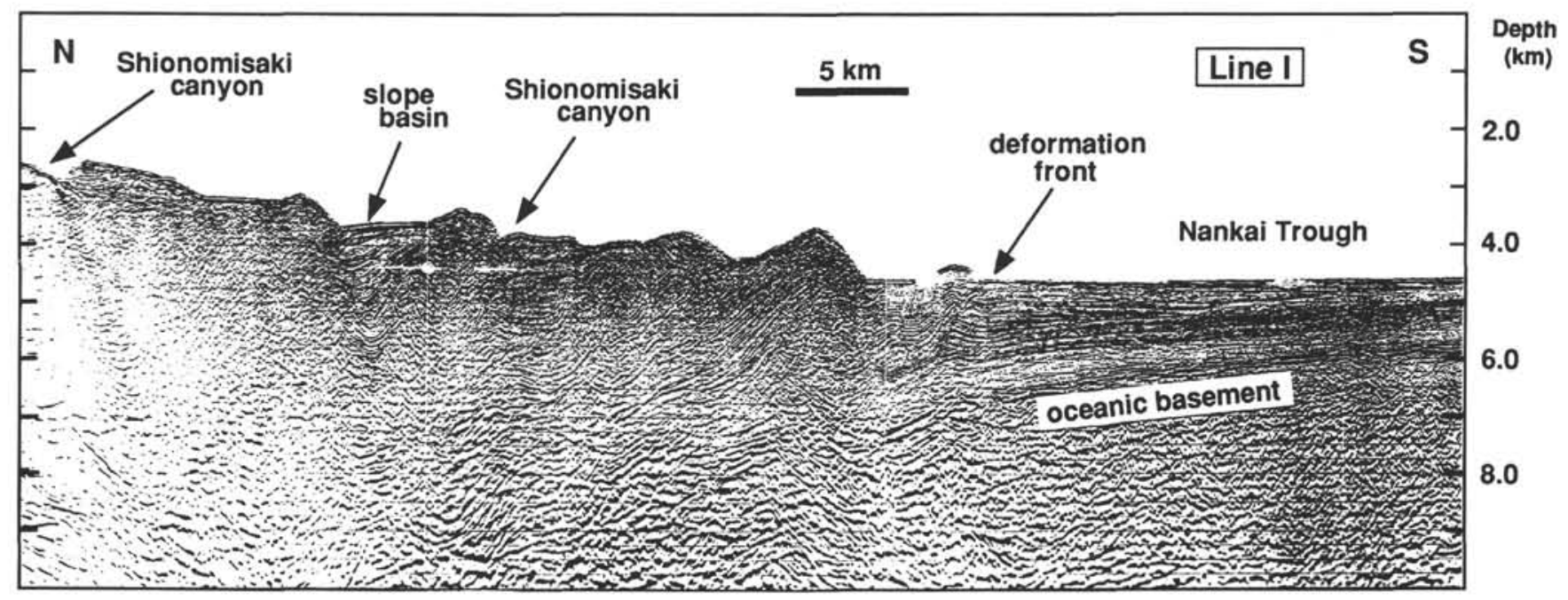

Figure 9. Multichannel seismic reflection profile along the Shionomisaki Canyon (line I, Kato et al., 1983). Note thick slope basin filling.

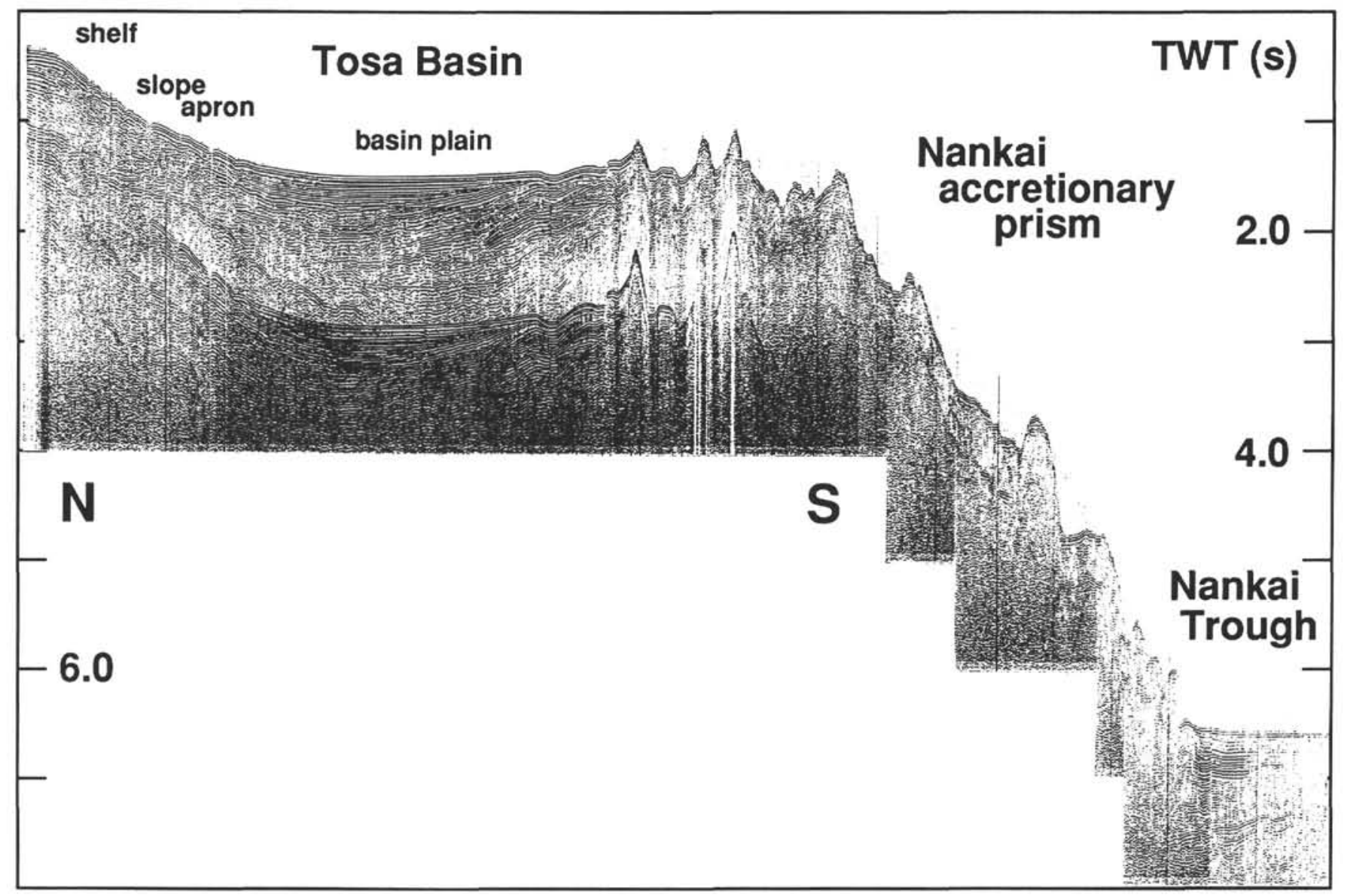

Figure 10. Single-channel seismic reflection profile (line 1-1) showing the Nankai Trough, Nankai accretionary prism, trench slope break, forearc basin (Tosa Basin), and shelf. 

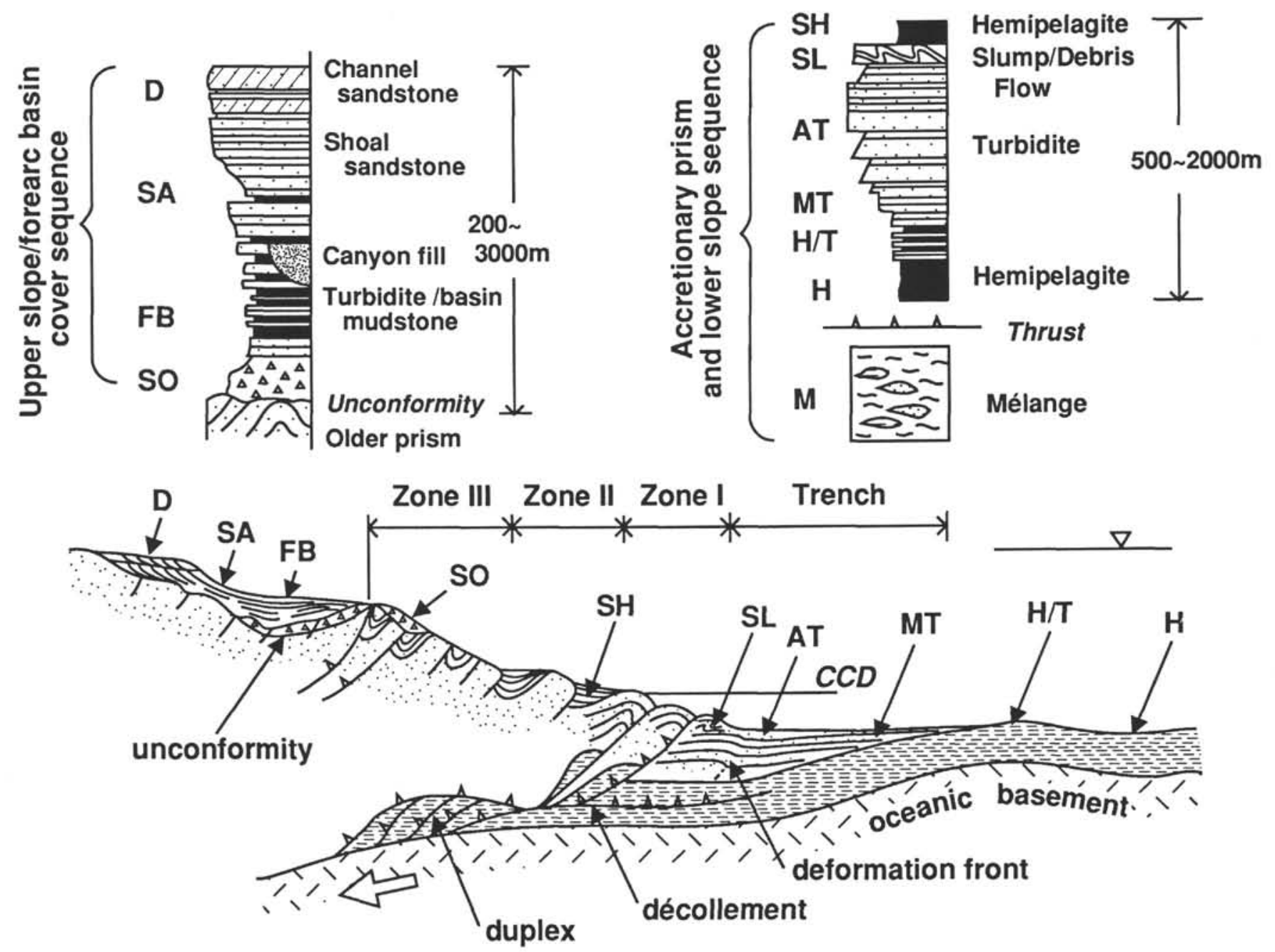

Figure 11. Sedimentary facies evolution model for the Nankai forearc region. $\mathrm{H}=$ hemipelagic mud, $\mathrm{H} / \mathrm{T}=$ hemipelagic mud/fine-grained turbidite transition, MT = marginal trench "overbank" turbidite (fining-upward cycle), AT = axial trench channel turbidite, $\mathrm{SL}=$ lower slope apron slumping $($ Zone I), $\mathrm{SH}=$ slope hemipelagic mud (Zone II), $\mathrm{SO}=$ upper slope olistostrome (Zone III), $\mathrm{FB}=$ forearc basin plain mud ( with canyon fill), $\mathrm{SA}=$ slope apron turbidite, $\mathrm{D}=$ progradational delta complex. Structural interpretation shows the zone of duplexing (major zone of underplating). Accretionary prism and lower slope basin sequence can be folded and faulted and a part of the prism becomes melange, especially where shear is concentrated.

Table 1. Nature of early Miocene submarine unconformity within the Tertiary Shimanto Belt.

\begin{tabular}{|c|c|c|c|c|}
\hline Overlying sequence & $\begin{array}{l}\text { Age } \\
(\mathrm{Ma})\end{array}$ & Underlying sequence & $\begin{array}{l}\text { Age } \\
\text { (Ma) }\end{array}$ & $\begin{array}{l}\text { Minimum duration } \\
\text { of hiatus (m.y.) }\end{array}$ \\
\hline $\begin{array}{l}\text { Misaki Group } \\
\text { (slope to shelf facies) }\end{array}$ & $22-15$ & $\begin{array}{l}\text { Shimizu Formation } \\
\text { (deformed turbidite) }\end{array}$ & $40-24$ & 2 \\
\hline $\begin{array}{l}\text { Shijujiyama Formation } \\
\text { (slope basin) }\end{array}$ & $17-15$ & $\begin{array}{l}\text { Nabae Group } \\
\text { (melange and turbidite) }\end{array}$ & $30-22$ & 5 \\
\hline $\begin{array}{l}\text { Tanabe Group } \\
\text { (slope to shelf facies) }\end{array}$ & $17-15$ & $\begin{array}{l}\text { Otonashigawa and Muro groups } \\
\text { (melange and turbidite) }\end{array}$ & $58-22$ & 5 \\
\hline $\begin{array}{l}\text { Kumano Group } \\
\text { (slope to shelf facies) }\end{array}$ & $17-15$ & $\begin{array}{l}\text { Otonashigawa and Muro groups } \\
\text { (melange and turbidite) }\end{array}$ & $58-22$ & 5 \\
\hline
\end{tabular}

